\title{
Killer Cell Immunoglobulin-Like Receptors (KIRs) Genotype and Haplotype Analysis in Iranians with Non-Melanoma Skin Cancers
}

\author{
Fahimeh Yousefinejad ${ }^{1}$, Farideh Jowkar ${ }^{2}$, Shaghik Barani ${ }^{3}$, Elham Jamali ${ }^{1}$, Ebrahim \\ Mahmoudi $^{4}$, Amin Ramezani ${ }^{3,5}$, Elham Mahmoudi Maymand ${ }^{3}$ and Abbas Ghaderi ${ }^{1,3^{*}}$ \\ ${ }^{1}$ Department of Immunology, School of Medicine, Shiraz University of Medical Sciences, Shiraz, Iran; \\ ${ }^{2}$ Department of Dermatology, School of Medicine, Shiraz University of Medical Sciences, Shiraz, \\ Iran; ${ }^{3}$ Shiraz Institute for Cancer Research, School of Medicine, Shiraz University of Medical Sciences, \\ Shiraz, Iran; ${ }^{4}$ Cellular and Molecular Research Center, Basic Health Sciences Institute, Shahrekord \\ University of Medical Sciences, Shahrekord, Iran; ${ }^{5}$ Department of Medical Biotechnology, School \\ of Advanced Medical Sciences and Technologies, Shiraz University of Medical Sciences, Shiraz, Iran
}

Received 25 August 2018; revised 3 November 2018; accepted 5 November 2018

\begin{abstract}
Background: The innate immune system against malignancies is mainly orchestrated by natural killer cells, which carry out killing mechanisms by using their receptors, such as killer immunoglobulin-like receptors (KIRs). This study was designed to determine the diversity of KIR genes in non-melanoma skin cancers. Methods: A total of 160 subjects with skin cancer, including 60 cases of squamous cell carcinoma and 100 cases of basal cell carcinoma $(B C C)$, and 270 healthy subjects formed the study groups. The sequence-specific polymerase chain reaction was carried out to detect the presence or absence of 16 KIR genes. Results: $K I R 3 D L 1(p=0.0381, O R=$ $4.78,95 \% \mathrm{Cl}=1.108$ to 20.62 ) increased in BCC patients compared to healthy controls. Conclusion: We concluded that the higher frequency of KIR3DL1 in BCC patients compared with healthy controls may increase the probability of developing BCC in Iranians. DOI: 10.29252/ibj.23.5.330
\end{abstract}

Keywords: Basal cell carcinoma, KIR, Natural killer cells, Receptors, Squamous cell carcinoma

Corresponding Authors: Abbas Ghaderi

Shiraz Institute for Cancer Research (ICR), School of Medicine, Shiraz University of Medical Sciences, Shiraz, Iran, P.O. Box: 71345-3119;

Tel.: (+98-713) 2303687; Fax: (+98-713) 2304952; E-mail: ghaderia@sums.ac.ir

\section{INTRODUCTION}

$\mathrm{B}$ ased on the WHO report, cancer is the second leading cause of mortality worldwide. Nonmelanoma skin cancer is more prevalent in males compared to females in $\operatorname{Iran}^{[1]}$ although the probability of metastasis of non-melanoma types is less than melanoma one; non-melanoma types are more $\operatorname{common}^{[2]}$. Keratinocyte carcinomas or non-melanoma skin cancer include(s) several groups of skin cancers different in their etiopathogenesis, clinical course, and management strategies; however, it generally mentioned as "basal-cell carcinoma (BCC) and squamous-cell carcinoma (SCC)", which is more aggressive in non-melanoma types ${ }^{[3]}$. The etiology of keratinocyte carcinomas, similar to other cancers, is multifactorial, which includes environmental factors such as long-term sun exposure ${ }^{[4,5]}$, human papillomavirus infection ${ }^{[6]}$, and host factors such as age $^{[7]}$, skin pigmentation, genetic factors ${ }^{[8]}$, and the immune system status ${ }^{[3]}$.

The impact of host genetic background on characteristics of skin cancer is highly important in a way that may lead to the change in behavior and cellular morphology; therefore, evaluation at the molecular level can be a tool for diagnosis and monitoring of the cancer. Human leukocyte antigen (HLA) has a key role in antigen presentation to T cells. Therefore, HLA I and II are among the molecules that are associated with susceptibility to different diseases 
like skin cancer ${ }^{[9]}$; for example, in one study it has been shown that the frequency of HLA-B27 and HLADR7 in patients with skin cancer is greater than in normal healthy controls ${ }^{[10]}$. Furthermore, the killer immunoglobulin-like receptor (KIR), a complex and diverse family of receptors expressing on natural killer (NK) cells, has similarly been studied for susceptibility or protection in various cancers ${ }^{[11]}$.

NK cells are composed of 5-15\% of peripheral blood lymphocyte circulating at a different variable level in the liver and lung ${ }^{[12]}$. NK cells have a critical role in fighting against stressed, infected, as well as transformed cells ${ }^{[13]}$. NK cells can distinguish these cells by a collection of activating and inhibitory germline-encoded receptors ${ }^{[14]}$. Attainment of NK cell receptors, unlike $\mathrm{T}$ and $\mathrm{B}$ lymphocytes, is independent of gene arrangements. A certain ligation of HLA class I variants with inhibitory NK cell receptors inhibits NK cells from activation. NK cells act in response to diminishing HLA class I expression on target cells, which is called "Missing self'. Subsequently, the NK cells secret the interferon-gamma (IFN- $\gamma$ ) that increases HLA class I expression on tumoral cells and the HLA class II on antigen-presenting cells; consequently, triggering both arms of the immune responses $^{[15]}$.

KIRs are the key receptors of NK cells ${ }^{[16]}$. A certain HLA class I is considered as KIR ligands categorizing three different epitopes, the $\mathrm{Bw} 4, \mathrm{C} 1$, and $\mathrm{C} 2$ epitopes, as well as HLA-A3/11 alleles. In particular, the recognition of $\mathrm{Bw} 4, \mathrm{C} 1$, and $\mathrm{C} 2$ epitopes by educated NK cells leads to subsequent interaction and destroy of the transformed target cells ${ }^{[17,18]}$. The high diversity of KIR gene family is determined by variable gene content in haplotypes and allelic polymorphism ${ }^{[19]}$. Among 16 KIR genes, KIR3DL3, 3DL2, 2DL4, and $3 D P 1$, as framework genes, exist in approximately all individuals. The KIR haplotypes are divided into A and $\mathrm{B}$ groups based on their gene content ${ }^{[20]}$. Group A haplotypes have specified gene contents (KIR3DL3, 2DL3, 2DP1, 2DL1, 3DP1, 2DLA, 3DL1, 2DS4, and $3 D L 2)$. In contrast, group $\mathrm{B}$ haplotypes have many variable genes (KIR2DL2-2DL5-2DS1-2DS2-2DS3$2 D S 5-3 D S 1$ ) that did do not occur in A haplotype. To find out the impact of $K I R$ genes content on the risk of non-melanoma skin cancers development, the KIR typing was performed in 160 patients and 270 healthy controls.

\section{MATRIALS AND METHODS}

\section{Study population}

The patient group was consisted of 160 nonmelanoma skin cancer, $100 \mathrm{BCC}$ and 60 SCC which were compared to 270 healthy controls from Fars Province of Iran. The patients and healthy controls were age-sex matched with negative family history of cancer (Table 1). The cases were recruited at Shahid Faghihi Hospital, Shiraz, Iran. The research was approved by the Medical Research Ethics Committee in Shiraz University of Medical Sciences (EC-93767306).

\section{KIR genotyping}

DNA of EDTA-treated blood samples were extracted using Qiagen QIAamp DNA Blood Mini Kit (Germany). We used a sequence-specific polymerase chain reaction (SSP-PCR) method with certain PCR conditions for detection of KIR genes, which was previously described by Barani et al. ${ }^{[21]}$. PCR was performed using Eurofin Genomics primers (Ebersberg, Germany). Subsequently, $5 \mu \mathrm{l}$ of PCR products were electrophoresed on $2 \%$ agarose gels and detected by a UV transilluminator. The panel of 10 UCLA KIR exchange DNA was applied to confirm specificity and accuracy of the test ${ }^{[22]}$.

\section{Statistical analysis}

We used direct counting to determine the frequency of each gene, haplotype and $\mathrm{Bx}$ subsets, and gene clusters. The frequencies in patients compared with healthy controls were calculated for two-tailed Chisquare with Yates' correction, and $p<0.05$ was considered to be statistically significant. Odds ratio and the $95 \%$ confidence intervals were reported as well. Based on linkage disequilibrium in the KIR system, two clusters, defined as C4 and T4, were characterized at the telomeric and centromeric half ${ }^{[23,24]}$ and calculated as described previously ${ }^{[25]}$.

\section{RESULTS}

\section{KIRs gene content diversity in $\mathrm{BCC}$ and SCC patients}

We studied 430 individuals who represented BCC and SCC patients as well as healthy controls to find out the impact of KIR genes content on the risk of developing non-melanoma skin cancers. The framework genes existed in all the individuals. We

Table 1. Gender distribution of the cases and controls

\begin{tabular}{lccc}
\hline Gender & $\begin{array}{c}\text { BCC } \\
(\mathbf{n}=\mathbf{1 0 0})\end{array}$ & $\begin{array}{c}\text { SCC } \\
(\mathbf{n}=\mathbf{6 0})\end{array}$ & $\begin{array}{c}\text { Controls } \\
(\mathbf{n}=\mathbf{2 7 0})\end{array}$ \\
\hline Male \% (n) & $39(39)$ & $26.6(16)$ & $29.3(79)$ \\
Female \% (n) & $61(61)$ & $73.4(44)$ & $70.7(191)$ \\
Mean age (SD) & $61(17)$ & $66.0(15)$ & $63.0(12)$ \\
\hline
\end{tabular}


observed a significantly higher frequency of KIR $3 D L 1$ in the BCC compared to the healthy controls $(98 \%$ vs. $91.1 \%, p=0.0381, \mathrm{OR}=4.78,95 \% \mathrm{CI}=1.108$ to 20.62) but was not significant, based on adjusted $p$ value $<0.025$ after Bonferroni correction. However, in the comparison between the SCC and controls, we did not observe any significant difference (Table 2), but we observed 40 distinct KIR genotypes in the study population. There were 10 unique genotypes (Table 3 ), which were only present in one individual, (five in patients and five in healthy controls). We rechecked and confirmed unique genotypes by different sets of primers designed by Ashouri et al. ${ }^{[25]}$.

\section{KIR2DS4 variants distribution in $\mathrm{BCC}$ and $\mathrm{SCC}$ patients}

Different variants of KIR2DS4 have previously been determined in many research studies ${ }^{[21,26-28]}$. To study the frequency of KIR2DS4 variants, we categorized the study population into three groups: (A) 2DS4Del: deleted variant of KIR2DS4, (B) 2DS4Full: full-length KIR2DS4, and (C) 2DS4Full/Del: full-length and deleted variants of KIR2DS4. Only one variant of 2DS4 (2DS4*001 or full length) encodes a functional protein acting as a membrane receptor. By investigating the possibility of any significant relationship between the disease and variants of $2 D S 4$, we observed that the full length of $2 D S 4$ was significantly higher in the BCC patients compared to the controls $(p=0.0415, \mathrm{OR}=2.01,95 \% \mathrm{CI}=1.074$ to 3.781) but was not significant after Bonferroni correction, we, however, found no significant difference between the patients with SCC and the controls (Table 4).

\section{The frequency of $\mathrm{AA}$ and $\mathrm{Bx}$ genotypes}

The frequency of AA genotype (genotype \#1), the homozygote combination of A haplotypes, occurred in higher frequency in the cases compared to the controls, but this difference was not statistically significant.

Table 2. Frequency of KIR genes in BCC, SCC, and healthy controls

\begin{tabular}{|c|c|c|c|c|c|c|c|c|c|}
\hline \multirow{2}{*}{$\begin{array}{l}\text { KIR } \\
\text { gene }\end{array}$} & \multirow{2}{*}{$\begin{array}{c}\text { BCC } \\
(n=100)\end{array}$} & \multirow{2}{*}{$\begin{array}{c}\mathrm{SCC} \\
(\mathrm{n}=60)\end{array}$} & \multirow{2}{*}{$\begin{array}{c}\text { Controls } \\
(\mathrm{n}=\mathbf{2 7 0})\end{array}$} & \multicolumn{3}{|c|}{ BCC vs. control } & \multicolumn{3}{|c|}{ SCC vs. control } \\
\hline & & & & $p$ value & OR & $\% 95 \mathrm{CI}$ & $p$ value & OR & $\mathbf{9 5} \% \mathbf{C I}$ \\
\hline \multicolumn{10}{|c|}{ A haplotypes associated-KIR genes } \\
\hline $2 D L 1$ & $100.0(100)$ & $100.0(60)$ & $100(270)$ & _ & NA & & - & NA & \\
\hline $2 D L 3$ & $86.0(86)$ & $90.0(54)$ & $89.2(241)$ & 0.36 & 0.73 & $0.37-1.46$ & 1.00 & 1.08 & $0.42-2.73$ \\
\hline $3 D L 1$ & $98.0(98)$ & $90.0(54)$ & $91.1(246)$ & $\mathbf{0 . 0 3 8 1}^{* \dagger}$ & 4.78 & $1.10-20.6$ & 0.80 & 0.87 & $0.34-2.25$ \\
\hline $2 D S 4$ & $98.0(98)$ & $93.3(56)$ & $91.8(248)$ & 0.0581 & 4.34 & $1.00-18.84$ & 1.00 & 1.24 & $0.41-3.74$ \\
\hline \multicolumn{10}{|c|}{ B haplotypes associated-KIR genes } \\
\hline $2 D L 2$ & $62.0(62)$ & $61.6(37)$ & $65.9(178)$ & 0.54 & 0.84 & $0.52-1.35$ & 0.55 & 0.83 & $0.46-1.48$ \\
\hline $2 D L 5$ & $64.0(64)$ & $66.6(40)$ & $62.9(170)$ & 0.90 & 1.04 & $0.64-1.68$ & 0.65 & 1.17 & $0.65-2.12$ \\
\hline $3 D S 1$ & $42.0(42)$ & $36.6(22)$ & 37.7 (102) & 0.47 & 1.19 & $0.74-1.90$ & 0.11 & 0.62 & $0.36-1.08$ \\
\hline $2 D S 1$ & $42.0(42)$ & $36.6(22)$ & 45.9 (124) & 0.55 & 0.85 & $0.53-1.35$ & 0.19 & 0.68 & $0.38-1.21$ \\
\hline $2 D S 2$ & $61.0(61)$ & $65.0(39)$ & $61.8(167)$ & 0.28 & 1.30 & $0.81-2.09$ & 0.76 & 1.14 & $0.63-2.05$ \\
\hline $2 D S 3$ & $51.0(51)$ & $50.0(30)$ & $45.1(122)$ & 0.34 & 1.26 & $0.79-1.99$ & 0.56 & 1.21 & $0.69-2.12$ \\
\hline $2 D S 5$ & $28.0(28)$ & $31.6(19)$ & $32.9(89)$ & 0.38 & 0.79 & $0.47-1.31$ & 0.88 & 0.94 & $0.51-1.71$ \\
\hline
\end{tabular}

Framework genes/pseudogenes

\begin{tabular}{|c|c|c|c|c|c|c|c|c|c|}
\hline $2 D L 4$ & $100(100)$ & $100(60)$ & $100(270)$ & - & NA & & - & NA & \\
\hline $3 D L 2$ & 100 (100) & $100(60)$ & $100(270)$ & - & NA & & - & NA & \\
\hline $3 D L 3$ & $100(100)$ & $100(60)$ & $100(270)$ & - & NA & & - & NA & \\
\hline $2 D P 1$ & $100(100)$ & $100(60)$ & 99.6 (269) & 1.00 & 1.12 & $0.04-27.7$ & 1.00 & 0.67 & $0.02-16.75$ \\
\hline $3 D P 1$ & $100(100)$ & $100(60)$ & $100(270)$ & _ & NA & & & NA & \\
\hline
\end{tabular}

Frequency of KIR genes was expressed as the percentage and defined as the number of individuals with KIR genes (N+) divided by a number of individuals studies in the given study group (n). Two-tailed Fisher's exact probability (p) test, Odd ratio with 95\% CI, was calculated by Graphpad Prism software, and ${ }^{*} p<0.05$ was considered statistically significant, based on two-tailed Chi-square with Yates' correction. NA, not available; ${ }^{\dagger} p<0.025$, statistically non-significant, based on Bonferroni correction 
Table 3. KIR genotypes distribution in the study population

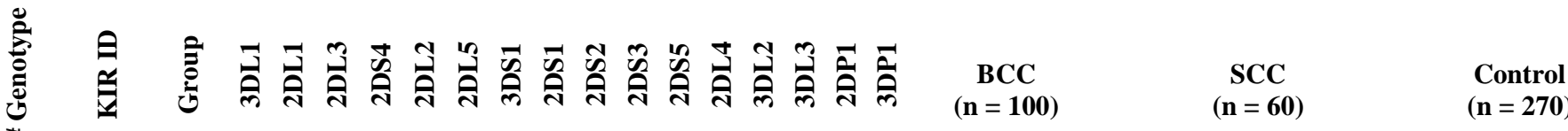

\begin{tabular}{|c|c|c|c|c|c|c|c|}
\hline & & $\begin{array}{c}\mathrm{F} \% \\
(\mathrm{~N}+)\end{array}$ & $\begin{array}{c}\mathrm{F} \% \\
(\mathrm{~N}+)\end{array}$ & $\begin{array}{c}\mathrm{F} \% \\
(\mathrm{~N}+)\end{array}$ & $\begin{array}{c}\mathrm{F} \% \\
(\mathrm{~N}+)\end{array}$ & $\begin{array}{c}\mathrm{F} \% \\
(\mathrm{~N}+)\end{array}$ & $\begin{array}{c}\mathrm{F} \% \\
(\mathrm{~N}+)\end{array}$ \\
\hline 1 & $1 \quad$ AA & 23.0 & 23 & 23.33 & 14 & 20 & 54 \\
\hline 2 & 14 & 1.0 & 1 & & & 0.74 & 2 \\
\hline 3 & 23 & & & & & 0.37 & 1 \\
\hline 4 & 200 & 1.0 & 1 & & & 0.74 & 2 \\
\hline 5 & 2 & 9.0 & 9 & 11.66 & 7 & 6.66 & 18 \\
\hline 6 & 27 & 1.0 & 1 & & & 0.74 & 2 \\
\hline 7 & 8 & 3.0 & 3 & & & & \\
\hline 8 & 10 & & & 1.66 & 1 & & \\
\hline 9 & 12 & & & 1.66 & 1 & 0.37 & 1 \\
\hline 10 & 19 & & & & & 3.33 & 9 \\
\hline 11 & 18 & & & & & 1.11 & 3 \\
\hline 12 & 58 & 1.0 & 1 & & & & \\
\hline 13 & 4 & 11.0 & 11 & 8.33 & 5 & 11.85 & 32 \\
\hline 14 & 31 & 1.0 & 1 & 1.66 & 1 & 1.11 & 3 \\
\hline 15 & 9 & & & & & 1.85 & 5 \\
\hline 16 & 3 & 3.0 & 3 & 1.66 & 1 & 3.33 & 9 \\
\hline 17 & 5 & 16.0 & 16 & 20.00 & 12 & 8.51 & 23 \\
\hline 18 & 13 & & & 1.66 & 1 & 1.48 & 4 \\
\hline 19 & 11 & 1.0 & 1 & 1.66 & 1 & 4.81 & 13 \\
\hline 20 & 7 & 5.0 & 5 & 1.66 & 1 & 4.44 & 12 \\
\hline 21 & $382 \mathrm{Bx}$ & & & & & 2.22 & 6 \\
\hline 22 & 6 & 8.0 & 8 & 8.33 & 5 & 8.14 & 22 \\
\hline 23 & 144 & & & & & 0.37 & 1 \\
\hline 24 & 190 & & & 1.66 & 1 & 0.37 & 1 \\
\hline 25 & 81 & & & & & 0.74 & 2 \\
\hline 26 & 297 & & & 1.66 & 1 & & \\
\hline 27 & 180 & 1.0 & 1 & & & & \\
\hline 28 & 317 & & & & & 0.74 & 2 \\
\hline 29 & 71 & 3.0 & 3 & 6.66 & 4 & 4.44 & 12 \\
\hline 30 & 113 & 1.0 & 1 & & & 2.22 & 6 \\
\hline 31 & 90 & 4.0 & 4 & & & 0.74 & 2 \\
\hline 32 & 73 & 5.0 & 5 & & & 1.11 & 3 \\
\hline 33 & 308 & & & & & 0.37 & 1 \\
\hline 34 & 69 & & & & & 2.22 & 6 \\
\hline 35 & 117 & & & & & 0.37 & 1 \\
\hline 36 & 75 & 1.0 & 1 & & & 1.48 & 4 \\
\hline 37 & 68 & 1.0 & 1 & & & & \\
\hline 38 & 70 & & & 5.00 & 3 & 2.22 & 6 \\
\hline 39 & 86 & & & & & 0.37 & 1 \\
\hline 40 & 87 & & & 1.66 & 1 & 0.37 & 1 \\
\hline
\end{tabular}

The presence and absence of a KIR gene are indicated by a shaded and white box, respectively. KIR ID was assigned by the Allele Frequency Net Database. 
Table 4. Distribution of KIR2DS4 variants in the study population

\begin{tabular}{|c|c|c|c|c|c|c|c|c|c|}
\hline \multirow[t]{2}{*}{ KIR2DS4 } & \multirow{2}{*}{$\begin{array}{c}\begin{array}{c}\text { BCC } \\
(n=98)\end{array} \\
\% \mathrm{~F}(\mathrm{~N}+)\end{array}$} & \multirow{2}{*}{$\begin{array}{c}\text { SCC } \\
(n=56)\end{array}$} & \multirow{2}{*}{$\begin{array}{c}\begin{array}{c}\text { Control } \\
(\mathrm{n}=248)\end{array} \\
\% \mathrm{~F}(\mathrm{~N}+)\end{array}$} & \multicolumn{3}{|c|}{ BCC vs. control } & \multicolumn{3}{|c|}{ SCC vs. control } \\
\hline & & & & $p$ value & OR & $95 \% \mathrm{CI}$ & $p$ value & OR & $95 \% \mathrm{CI}$ \\
\hline Del & $66.3(65)$ & $69.6(39)$ & $67.3(167)$ & 0.89 & 0.95 & $0.58-1.56$ & 0.87 & 1.11 & $0.59-2.08$ \\
\hline Full & $20.4(20)$ & $14.3(8)$ & $11.3(28)$ & $0.0415^{* \dagger}$ & 2.01 & $1.07-3.78$ & 0.49 & 1.31 & $0.59-2.09$ \\
\hline Full/Del & $12.2(12)$ & $14.3(8)$ & $19.7(49)$ & 0.11 & 0.56 & $0.28-1.19$ & 0.44 & 0.67 & $0.59-2.10$ \\
\hline Missing & $1.02(1)$ & $1.78(1)$ & $1.6(4)$ & 1.00 & 0.62 & $0.06-5.7$ & 1.00 & 0.90 & $0.59-2.11$ \\
\hline
\end{tabular}

The number (n) that is exhibited below each group is the number of people who were 2DS4 positive in each group, which is categorized into three types (Deletion, Full, and Full/Deletion) of 2DS4 allele. Two-tailed Fisher's exact probability (p) test, odd ratio with KI95\% CI was calculated by Graphpad Prism software; ${ }^{*} p<0.05$, statistically significant based on two-tailed Chi-square with Yates' correction; ${ }^{\dagger} p<0.025$, statistically non-significant based on Bonferroni correction.

Consequently, the frequencies of Bx genotypes were not significantly different between the cases and healthy controls (Table 5). Also, no significant difference was found in the carriers of $\mathrm{C} 4$ and $\mathrm{T} 4$ clusters between the cases and controls (Table 6).

\section{DISCUSSION}

The high prevalence of cancers has been observed in individuals with defective NK cell functions ${ }^{[2]}$. A long-term epidemiological study has reported that individuals with low NK cell activity are prone to high risk of developing different types of cancers ${ }^{[30]}$. In this study, almost all of the BCC patients were carriers of $K I R 3 D L 1$, a receptor binding to HLA-Bw4 epitope to transfer the inhibitory signal to NK cells. KIR3DL1 is a highly polymorphic allele (https://www.ebi.ac.uk /ipd/kir/ stats.html) with different spectra of cell surface expression. In consistency with this study, the combination of KIR3DL1 with less effective $\mathrm{Bw} 4^{\mathrm{T} 80}$ has been reported in primary melanoma patients compared to metastatic patients ${ }^{[31]}$, since KIR3DL1 generates a weaker inhibitory signal when an threonine residue is present at position 80 ( $\mathrm{Bw} 4 \mathrm{~T} 80)$. In contrast, the Bw4I80 epitope with an isoleucine at position 80 sends stronger inhibitory signals to NK cells ${ }^{[32]}$. Hence, the importance of investigating KIR receptors and HLA-KIR combinations in addition to KIR typing should be highlighted. It has previously been shown that the high frequency of KIR3DL1 in BCC with more activating KIR receptors could help to kill tumor cells with low/absence of HLA class I expression ${ }^{[33]}$. De Re et al. ${ }^{[34]}$ have reported that the presence of activating telomeric KIR receptors in the absence of KIR2DS4 and KIR3DL1 might increase the likelihood of complete response to chemotherapy in metastatic colorectal cancer patients. However, inhibitory KIRs are expressed on a group of effector/memory CD4+ and CD8+ T cells along with NK cells, and as a result, the inhibitory KIRs might decrease the antitumor responses of these cells. These data support a scheme that full competent NK cells with less activating KIR receptors may help to develop BCC cancer in some individuals.

Table 5. Frequency of KIR genotypes and haplotypes in BCC and SCC patients and healthy controls

\begin{tabular}{|c|c|c|c|c|c|c|c|c|c|c|}
\hline \multirow{2}{*}{$\begin{array}{l}\text { KIR } \\
\text { genotypes } \\
\text { and } \\
\text { haplotypes }\end{array}$} & & \multirow{2}{*}{$\begin{array}{c}\begin{array}{c}\text { BCC } \\
(\mathrm{n}=100)\end{array} \\
\% \mathrm{~F}(\mathrm{~N}+)\end{array}$} & \multirow{2}{*}{$\begin{array}{c}\begin{array}{c}\mathrm{SCC} \\
(\mathrm{n}=60)\end{array} \\
\% \mathrm{~F}(\mathrm{~N}+) \\
\end{array}$} & \multirow{2}{*}{$\begin{array}{c}\begin{array}{c}\text { Control } \\
(\mathrm{n}=270)\end{array} \\
\% \mathrm{~F}(\mathrm{~N}+)\end{array}$} & \multicolumn{3}{|c|}{ BCC vs. control } & \multicolumn{3}{|c|}{ SCC vs. control } \\
\hline & & & & & $p$ value & OR & $95 \% \mathrm{CI}$ & $p$ value & OR & $95 \% \mathrm{CI}$ \\
\hline Genotype & $\begin{array}{l}\mathrm{AA} \\
\mathrm{Bx}\end{array}$ & $\begin{array}{l}23.0(23) \\
77.0(77)\end{array}$ & $\begin{array}{l}23.3(14) \\
76.6(46)\end{array}$ & $\begin{array}{r}20.0(54) \\
80.0(216)\end{array}$ & 0.501 & 1.26 & $0.72-2.19$ & 0.69 & 1.21 & $0.62-2.37$ \\
\hline Haplotype & $\begin{array}{l}\text { A } \\
\text { B }\end{array}$ & $\begin{array}{r}53.5(107) \\
46.5(93)\end{array}$ & $\begin{array}{l}53.0(64) \\
47.0(56)\end{array}$ & $\begin{array}{l}50.9(275) \\
49.1(265)\end{array}$ & 0.97 & 1.01 & $0.64-1.58$ & 0.63 & 1.10 & $0.74-1.63$ \\
\hline
\end{tabular}

Frequency of KIR genotypes/haplotypes was expressed as percentage and defined as the number of individuals with genotype/haplotype $(\mathrm{N}+)$ divided by the number of individuals studies in the given study group (n). No significant $p$ value was found. 
Table 6. Frequency of KIR Bx genotypes and KIR clusters in BCC and SCC patients and healthy controls

\begin{tabular}{|c|c|c|c|c|c|c|c|c|c|}
\hline \multirow{2}{*}{$\begin{array}{l}\text { Bx genotypes and } \\
\text { KIR clusters }\end{array}$} & \multirow{2}{*}{$\begin{array}{c}\text { BCC } \\
(n=100) \\
\% \mathrm{~F}(\mathrm{~N}+)\end{array}$} & \multirow{2}{*}{$\begin{array}{c}\text { SCC } \\
(n=60)\end{array}$} & \multirow{2}{*}{$\begin{array}{c}\begin{array}{c}\text { Control } \\
(\mathrm{n}=270)\end{array} \\
\% \mathrm{~F}(\mathrm{~N}+)\end{array}$} & \multicolumn{3}{|c|}{ BCC vs. control } & \multicolumn{3}{|c|}{ SCC vs. control } \\
\hline & & & & $p$ value & OR & $95 \% \mathrm{CI}$ & $p$ value & OR & $95 \% \mathrm{CI}$ \\
\hline C4Tx genotype & $30.0(30)$ & $33.3(20)$ & $29.2(79)$ & 0.89 & 1.03 & $0.62-1.71$ & 0.53 & 1.20 & 0.662 .19 \\
\hline CxT4 genotype & $15.0(15)$ & $15.0(9)$ & $15.9(43)$ & 0.87 & 0.93 & $0.49-1.76$ & 1.00 & 0.93 & $0.42-2.03$ \\
\hline C4T4 genotype & $13.0(13)$ & $16.6(10)$ & $12.6(34)$ & 1.00 & 1.03 & $0.52-2.05$ & 0.40 & 1.38 & $0.64-2.99$ \\
\hline CxTx genotype & $19.0(19)$ & $11.6(7)$ & $22.2(60)$ & 0.56 & 0.82 & $0.46-1.46$ & 0.07 & 0.46 & $0.19-1.07$ \\
\hline $\mathrm{C} 4$ gene cluster & $43.0(43)$ & $50.0(30)$ & $41.8(113)$ & 0.91 & 1.03 & $0.69-1.53$ & 0.32 & 1.26 & $0.79-2.00$ \\
\hline T4 gene cluster & $28.0(28)$ & $31.6(19)$ & $28.5(77)$ & 1.00 & 0.97 & $0.61-1.56$ & 0.66 & 1.13 & $0.65-1.95$ \\
\hline
\end{tabular}

Two-tailed Fisher's exact probability (p) test was calculated by Graphpad Prism software, and $p<0.05$ was considered to be statistically significant. No significant $p$ value was found.

Higher frequency of KIR2DS4 full length carriers in BCC group is a clue showing the importance of inflammation in development and persistence of tumors. The $2 D S 4$ is an activating KIR that can activate NK cells, resulting in the secretion of IFN- $\gamma$, a proinflammatory cytokine with anti-tumor property that regulates the transcription of many immune response genes ${ }^{[35]}$. These events and activation of NK cells occur when 2DS4 is in the full length because all its other variants are non-functional. A number of confirmatory studies have shown that KIR $2 D S 4 * 001$ (the full variant of 2DS4) is associated with a relatively high viral load ${ }^{[36,37]}$ and transmission of HIV-1 ${ }^{[38]}$. Consistent with these findings, Bao et al. ${ }^{[39]}$ in their research have found an association between KIR2DS4*001 and acute graft-versus-host disease. In contrast, Barani et al. ${ }^{[21]}$ did not find any association between KIR2DS4 full length and patients with head and neck SCC but showed a protective role of KIR2DS4 Del against disease.

In the present study, we did not find any significant difference in the carrier frequencies of $\mathrm{AA}, \mathrm{Bx}$ genotypes, A and B haplogroups, as well as Bx clusters between the patients (SCC and BCC) and controls, while AA genotype resistance and CxT4 genotype susceptibility have been reported in SCC patients with head and neck cancer in Iranians ${ }^{[21]}$. The results of this study, as shown in Table 4, was consistent with the a previous study, "KIR gene content diversity in Iranian populations", supporting that the frequency of A haplotype was greater than B haplotype in Iranians (50.9\% A haplotype vs. $49.1 \%$ B haplotype in healthy control group $)^{[25]}$. That study also concluded that the $\mathrm{AB}$ genotype had higher frequency than $\mathrm{BB}$ genotype in Iranian populations, being consistent with our results in which the frequency of $\mathrm{AB}$ genotype was $61.8 \%$, while the $\mathrm{BB}$ genotype was $18.2 \%$ in the healthy controls (data not shown). Future studies of the KIRsHLA class I pattern in patients with non-melanoma skin cancer as well as $\gamma \delta \mathrm{T}$ cells, which have extent distribution in $\operatorname{skin}^{[40]}$ and functional studies of NK cells possessing KIR3DL1 in BCC patients, would be a valuable strategy to find out the effect of its presence on the NK cell meddling in cancer immunity.

\section{ACKNOWLEDGEMENTS}

This study was supported by a grant (no: 93-7306) from Shiraz University of Medical Sciences, Shiraz, Iran. We would like to thank Dr. Peyman Jafari for his valuable advice in the statistical analysis. This study was a part of MS.c. dissertation in Shiraz Institute for Cancer Research.

CONFLICT OF INTEREST. None declared.

\section{REFERENCES}

1. Razi S, Enayatrad M, Mohammadian-Hafshejani A, Salehiniya H, Fathali-Loy-Dizaji M, Soltani S. The Epidemiology of Skin Cancer and its Trend in Iran. International journal of preventive medicine 2015; 6: 64.

2. Horsham C, Auster J, Sendall MC, Stoneham M, Youl $\mathrm{P}$, Crane $\mathrm{P}$, Tenkate $\mathrm{T}$, Janda $\mathrm{M}$, Kimlin $\mathrm{M}$. Interventions to decrease skin cancer risk in outdoor workers: update to a 2007 systematic review. BMC research notes 2014; 7: 10.

3. Madan V, Lear JT, Szeimies RM. Non-melanoma skin cancer. The lancet 2010; 375(9715): 673-685.

4. Armstrong BK, Kricker A, English DR. Sun exposure and skin cancer. Australasian journal of dermatology 1997; 38 (Suppl 1): S1-S6.

5. English DR, Armstrong BK, Kricker A, Fleming C. Sunlight and cancer. Cancer causes and control 1997; 8(3): 271-283.

6. Harwood CA, Surentheran T, McGregor JM, Spink PJ, Leigh IM, Breuer J, Proby CM. Human papillomavirus 
infection and non-melanoma skin cancer in immunosuppressed and immunocompetent individuals. Journal of medical virology 2000; 61(3): 289-297

7. Diffey B, Langtry J. Skin cancer incidence and the ageing population. British journal of dermatology 2005; 153(3): 679-680.

8. Ho W, Murphy G. Update on the pathogenesis of post-transplant skin cancer in renal transplant recipients. British journal of dermatology 2008; 158(2): 217-224.

9. Streilein JW. Immunogenetic factors in skin cancer. The new England journal of medicine 1991; 325(12): 884-7.

10. Bavinck JB, Vermeer BJ, van der Woude F. Skin cancer and HLA antigens. The new England journal of medicine 1992; 326: 765-766.

11. Li JT, Guo C, Li ML, Wei YQ, Hou YF, Jiao YL, Zhao YR, Sun H, Xu J, Cao MF, Feng L, Yu GN, Gao L, Liu YQ, Zhang BC, Zhao JJ, Zhang HQ. Killer cell immunoglobulin-like receptor genes and their hla-c ligands in hashimoto thyroiditis in a chinese population. Endocrine practice 2016; 22(8): 935-940.

12. Cerwenka A, Lanier LL. Natural killer cells, viruses and cancer. Nature reviews immunology 2001; 1(1): 41-9.

13. Vilches C, Parham P. KIR: diverse, rapidly evolving receptors of innate and adaptive immunity. Annual review of immunology 2002; 20: 217-251.

14. Vivier E, Raulet DH, Moretta A, Caligiuri MA, Zitvogel L, Lanier LL, Yokoyama WM, Ugolini S. Innate or adaptive immunity? The example of natural killer cells. Science 2011; 331(6013): 44-49.

15. Vivier E, Tomasello E, Baratin M, Walzer T, Ugolini S. Functions of natural killer cells. Nature immunology 2008; 9(5): 503-510.

16. Lanier LL. NK cell recognition. Annual review of immunology 2005; 23: 225-274.

17. Parham P. MHC class I molecules and KIRs in human history, health and survival. Nature reviews immunology 2005; 5(3): 201-214.

18. Kim S, Poursine-Laurent J, Truscott SM, Lybarger L, Song YJ, Yang L, French AR, Sunwoo JB, Lemieux S, Hansen TH, Yokoyama WM. Licensing of natural killer cells by host major histocompatibility complex class I molecules. Nature 2005; 436(7051): 709-713.

19. Anfossi N, André P, Guia S, Falk CS, Roetynck S, Stewart CA, Breso V, Frassati C, Reviron D, Middleton D, Romagné F, Ugolini S, Vivier E. Human NK cell education by inhibitory receptors for MHC class I. Immunity 2006; 25(2): 331-342.

20. Uhrberg M, Valiante NM, Shum BP, Shilling HG, Lienert-Weidenbach K, Corliss B, Tyan D, Lanier LL, Parham P. Human diversity in killer cell inhibitory receptor genes. Immunity 1997; 7(6): 753-763.

21. Barani S, Khademi B, Ashouri E, Ghaderi A. KIR2DS1, 2DS5, 3DS1 and KIR2DL5 are associated with the risk of head and neck squamous cell carcinoma in Iranians. Human immunology 2018; 79(4): 218-223.

22. Ashouri E, Ghaderi A, Reed E, Rajalingam R. A novel duplex SSP-PCR typing method for KIR gene profiling. Tissue antigens 2009; 74(1): 62-67.

23. Du Z, Gjertson DW, Reed EF, Rajalingam R. Receptorligand analyses define minimal killer cell Ig-like receptor (KIR) in humans. Immunogenetics 2007; 59(1): $1-15$.

24. Pyo CW, Guethlein LA, Vu Q, Wang R, Abi-Rached L, Norman PJ, Marsh SG, Miller JS, Parham P, Geraghty DE. Different patterns of evolution in the centromeric and telomeric regions of group A and B haplotypes of the human killer cell Ig-like receptor locus. PLoS one 2010; 5(12): e15115.

25. Ashouri E, Farjadian S, Reed EF, Ghaderi A, Rajalingam R. KIR gene content diversity in four Iranian populations. Immunogenetics 2009; 61(7): 483492.

26. Jamali E, Barani S, Yousefinejad F, Ariafar A, Talei GR, Ghaderi A. KIRs gene content diversity in Iranians with urothelial bladder cancer. Molecular biology reports 2018; 45(5): 713-719.

27. Wu X, Yao Y, Bao X, Zhou H, Tang X, Han Y, Ma X, Liu Y, Chen J, Zhou H, Jing S, Gu B, Xu Y, Sun A, He $\mathrm{J}, \mathrm{Wu} \mathrm{D}$. KIR2DS4 and its variant KIR1D are associated with acute graft-versus-host disease, cytomegalovirus, and overall survival after siblingrelated HLA-matched transplantation in patients with donors with KIR gene haplotype A. biology of blood and marrow transplantation 2016; 22(2): 220-225.

28. Giebel S, Nowak I, Wojnar J, Krawczyk-Kulis M, Holowiecki J, Kyrcz-Krzemien S, Kusnierczyk P. Association of KIR2DS4 and its variant KIR1D with leukemia. Leukemia 2008; 22(11): 2129-2130.

29. Talmadge JE, Meyers KM, Prieur DJ, Starkey JR. Role of natural killer cells in tumor growth and metastasis: C57BL/6 normal and beige mice. Journal of the National Cancer Institute 1980; 65(5): 929-935.

30. Imai K, Matsuyama S, Miyake S, Suga K, Nakachi K. Natural cytotoxic activity of peripheral-blood lymphocytes and cancer incidence: an 11-year follow-up study of a general population. The lancet 2000; 356(9244): 1795-1799.

31. Naumova E, Mihaylova A, Stoitchkov K, Ivanova M, Quin L, Toneva M. Genetic polymorphism of NK receptors and their ligands in melanoma patients: prevalence of inhibitory over activating signals. Cancer immunology, immunotherapy 2005; 54(2): 172-178.

32. Cariani E, Pilli M, Zerbini A, Rota C, Olivani A, Zanelli P, Zanetti A, Trenti T, Ferrari C, Missale G. HLA and killer Immunoglobulin-like receptor genes as outcome predictors of hepatitis $\mathrm{C}$ virus-related hepatocellular carcinoma. Clinical cancer research 2013; 19(19): 5465-5473.

33. Vineretsky KA, Karagas MR, Christensen BC, KurigerLaber JK, Perry AE, Storm CA, Nelson HH. Skin cancer risk is modified by KIR/HLA interactions that influence the activation of natural killer immune cells. Cancer research 2016; 76(2): 370-376.

34. De Re V, Caggiari L, De Zorzi M, Talamini R, Racanelli V, D'Andrea M, Buonadonna A, Zagonel V, Cecchin E, Innocenti F, Toffoli G. Genetic diversity of the KIR/HLA system and outcome of patients with metastatic colorectal cancer treated with chemotherapy. PLoS one 2014; 9(1): e84940.

35. Merino AM, Dugast A-S, Wilson CM, Goepfert PA, 
Alter G, Kaslow RA, Tang J. KIR2DS4 promotes HIV1 pathogenesis: new evidence from analyses of immunogenetic data and natural killer cell function. PLoS one 2014; 9(6): e99353.

36. Merino A, Malhotra R, Morton M, Mulenga J, Allen S, Hunter E, Tang J, Kaslow RA. Impact of a functional KIR2DS4 allele on heterosexual HIV-1 transmission among discordant Zambian couples. Journal of infectious diseases 2011; 203(4): 487-495.

37. Olvera A, Pérez-Álvarez S, Ibarrondo J, Ganoza C, Lama JR, Lucchetti A, Cate S, Hildebrand W, Bernard N, Gomez L, Sanchez J, Brander C. The HLA-C* 04: 01/KIR2DS4 gene combination and human leukocyte antigen alleles with high population frequency drive rate of HIV disease progression. AIDS 2015; 29(5): 507-517.

38. Yu H, Liu F, Sansas B, Kang B, Preville X, Wu X,
Chang J, Micol R, Wang J, Meng X. Typing of killercell immunoglobulin-like receptors and their cognate human leukocyte antigen class I ligands predicts survival of Chinese Han patients with metastatic nonsmall-cell lung cancer. Molecular and clinical oncology 2017; 6(2): 279-285.

39. Bao X, Hou L, Sun A, Qiu Q, Yuan X, Chen M, Chen Z, He J. The impact of KIR2DS4 alleles and the expression of KIR in the development of acute GVHD after unrelated allogeneic hematopoietic SCT. Bone marrow transplantation 2010; 45(9): 1435-1441.

40. Ebert LM, Meuter S, Moser B. Homing and function of human skin $\gamma \delta$ T cells and NK cells: relevance for tumor surveillance. The journal of immunology 2006; 176(7): 4331-4336. 